RMD Open

Rheumatic \&

Musculoskeletal

Diseases

To cite: Wendling D.

Psoriatic arthritis: an evolving matter. RMD Open 2015;1:

e000006. doi:10.1136/

rmdopen-2014-000006

- Prepublication history for this paper is available online To view these files please visit the journal online (http://dx.doi.org/10.1136/ rmdopen-2014-000006).

Received 8 October 2014 Revised 29 0ctober 2014 Accepted 30 October 2014

CrossMark

Department of

Rheumatology, CHRU de Besançon, University

Teaching Hospital, and University of Franche-Comté, Besançon, France

Correspondence to Professor Daniel Wendling; dwendling@chu-besancon.fr

\title{
Psoriatic arthritis: an evolving matter
}

\section{Daniel Wendling}

Psoriatic arthritis is a multifaceted disease, raising the discussion of its position between a single isolated disease or a part or subset of spondyloarthritis. New developments in the several fields of knowledge are paving the way for a new look at this disease.

\section{A STORY OF CLASSIFICATION CRITERIA}

Several sets of criteria were proposed over the years for classifying psoriatic arthritis. Recent are the CASPAR criteria. ${ }^{1}$ The patient must have inflammatory articular disease (joint, spine or entheses) with three points from the following five categories: (1) evidence of current psoriasis or a personal or familial history of psoriasis; (2) typical psoriatic nail dystrophy; (3) absence of rheumatoid factor; (4) current dactylitis or a history of dactylitis; (5) radiographic evidence of juxta articular new bone formation. A score of 2 is assigned to current psoriasis; all other features are assigned a score of 1 . These classification criteria allow the inclusion of many patients and various clinical phenotypes (including axial forms) in a definition of psoriatic arthritis. The question is if psoriatic arthritis fits into the spondyloarthritis frame too. Over the past few years, the ASAS group (Assessment in SpondyloArthritis international Society) developed and proposed new classification criteria for axial and peripheral forms of spondyloarthritis. ${ }^{2}$ These classifications allow the recognition of several clinical or phenotypical presentations of the disease ${ }^{3}$ : axial spondyloarthritis, radiographic (corresponding to ankylosing spondylitis), nonradiographic; peripheral articular erosive or not erosive, and enthesitis spondyloarthitis. These presentations are somewhat different from the several phenotypic forms of psoriatic arthritis described earlier by Moll and Wright in $1972,{ }^{4}$ but this illustrates that, in current practice, it is more the phenotypic presentation than the nosological classification that matters.

\section{NEW EPIDEMIOLOGICAL FINDINGS}

Under these circumstances, some epidemiological data are highlighted. The prevalence of psoriatic arthritis is estimated as $0.14 \%$ in a nationwide study in France, ${ }^{5}$ and psoriatic arthritis in $6-24 \%$ of patients with skin psoriasis $^{6}$ with some particularities of the skin disease associated with arthritis: scalp, intergluteal/perianal lesions and nail involvement. A trend for an association between high Psoriasis Area and Severity Index (PASI) and psoriatic arthritis is suggested. ${ }^{6}$ The relation between nail involvement and enthesitis is underlined, ${ }^{7}$ evaluated by several imaging techniques. ${ }^{8-10}$

Like in other inflammatory arthritides, comorbidities are now recognised as factors to be screened and taken into account. Many studies have shown a significant increased risk of cardiovascular events, ${ }^{11}$ but increased mortality is not clearly demonstrated. ${ }^{11} 12$ Obesity may be associated with an increased risk of incident psoriatic arthritis. ${ }^{13}$ Metabolic syndrome and insulin resistance were found to be highly prevalent in psoriatic arthritis and independently associated with the severity of the rheumatic disease. ${ }^{14}$ Finally, smoking appears as a major environmental factor for psoriatic arthritis. Smoking is associated with the risk of psoriatic arthritis in the general population, ${ }^{15}$ with a relative risk of 1.54 for past smokers and 3.13 for current smokers, compared with never smokers. Moreover, smoking is associated with a more severe disease, ${ }^{15-17}$ and a poorer response to tumour necrosis factor (TNF) blockers. ${ }^{18}$

\section{NEW TOOLS FOR EVALUATION}

Evaluation of the disease is more standardised, taking into account the various aspects of the disease. Besides tools extrapolated from rheumatoid arthritis (for peripheral joints) or spondyloarthritis (for axial involvement), or dermatology (PASI skin score, Nail Psoriasis Severity Index (NAPSI) score), new instruments have been developed specifically for psoriatic arthritis. ${ }^{19}$ These are response criteria, and besides PSARC (psoriatic arthritis response criteria), new disease activity scores (PASDAS, Psoriatic Arthritis Disease Activity Score; MDA, Minimal Disease Activity; 
CPDAI, Composite Psoriatic Disease Activity Index; DAPSA, Disease Activity Index for Psoriatic Arthritis), as well as patient-reported outcome measures (PsAID: Psoriatic Arthritis Impact of Disease) were proposed. ${ }^{20}$ These not only allow the quantification and standardisation of the disease evaluation and treatment response, but also provide composite scores encompassing the whole spectrum of the phenotypic heterogeneity of psoriatic arthritis. New imaging techniques (ultrasound, ${ }^{8} 9$ $\mathrm{MRI}^{21}$ and PET scanner ${ }^{10}$ ) may be used as tools for diagnosis and evaluation assessment.

\section{NEW THERAPEUTIC STRATEGIES AND RECOMIMENDATIONS}

Recommendations for the management of psoriatic arthritis have been developed and tailored to the presentation of the disease. ${ }^{22}$ New concepts, validated in other diseases, may be used in psoriatic arthritis management. This is the case for the treat-to-target strategy, proposed in spondyloarthritis and psoriatic arthritis, ${ }^{23}$ with the first evaluation of this strategy with tight control in a trial in psoriatic arthritis (TICOPA).$^{24}$ The latest national recommendations have taken these considerations into account, as well as the polymorphism of the disease. ${ }^{25} 26$ However, the eventuality of a window of opportunity remains to be demonstrated, especially in axial forms. ${ }^{27}$

\section{NEW PATHOPHYSIOLOGICAL DEVELOPMENTS AND NEW TREATMENT OPTIONS}

Methotrexate is a first-line disease-modifying antirheumatic drug (DMARD), as recommended, ${ }^{22} 25$ and an anchor drug for biologics, even if its efficacy has not been evidence-based demonstrated. ${ }^{28}$ Anti-TNF agents represent a major breakthrough in the treatment of the different presentations of psoriatic arthritis. ${ }^{26}$ Knowledge in the immune pathogenesis of the disease led to new targeted therapeutic approaches.

Psoriasis and psoriatic arthritis are cytokine-driven diseases. In the cytokine network involved in psoriatic arthritis, the IL-23/Th17 pathway is currently under the spotlight. ${ }^{29}{ }^{30}$ This allows the development of treatment strategies based on IL-23 or IL-17 targeting, using monoclonal antibodies against the cytokine or its receptor, or soluble receptors. Potential targets include each of the IL-23 subunits ( $\mathrm{p} 40$ and p19), IL-17A and IL-17 receptor, and randomised controlled studies provided results in psoriatic arthritis with ustekinumab (monoclonal anti-p40 IL-12/23 antibody), secukinumab (monoclonal antibody directed against IL-17A) and brodalumab (monoclonal antibody directed against the IL-17 receptor), with significantly positive results compared to placebo, regarding clinical efficacy on rheumatological and skin expression. ${ }^{29}$ Ustekinumab is licensed in Europe for patients with psoriatic arthritis. Other options are possible as, for example, new anti-IL-17A antibodies (ixekizumab), anti-p19IL-23 antibodies and
anti-IL-23 receptor antibodies, as well as soluble receptors for IL-23 and IL-17.

Small molecules may also have a future in the treatment strategy of psoriatic arthritis. Apremilast, a phosphodiesterase four inhibitor, demonstrated significant results in several situations of psoriatic arthritis ${ }^{26} 31$ (and received recent Food and Drug Administration (FDA) approval to treat adults with active psoriatic arthritis), and kinase inhibitors are under evaluation in this condition.

\section{CONCLUSION}

Psoriatic arthritis is not a concept, but a live disease with a phenotypical polymorphism. There is no doubt about new developments in the future in this part of rheumatic musculoskeletal diseases.

Competing interests None.

Provenance and peer review Commissioned; externally peer reviewed.

Data sharing statement No additional data are available.

Open Access This is an Open Access article distributed in accordance with the Creative Commons Attribution Non Commercial (CC BY-NC 4.0) license, which permits others to distribute, remix, adapt, build upon this work noncommercially, and license their derivative works on different terms, provided the original work is properly cited and the use is non-commercial. See: http:// creativecommons.org/licenses/by-nc/4.0/

\section{REFERENCES}

1. Taylor W, Gladman D, Helliwell $P$, et al. Classification criteria for psoriatic arthritis: development of new criteria from a large international study. Arthritis Rheum 2006;54:2665-73.

2. Rudwaleit M, van der Heijde D, Landewé R, et al. The Assessment of SpondyloArthritis international Society classification criteria for peripheral spondyloarthritis and for spondyloarthritis in general. Ann Rheum Dis 2011;70:25-31.

3. Claudepierre $P$, Wendling $D$, Breban $M$, et al. Ankylosing spondylitis, spondyloarthropathy, spondyloarthritis, or spondylarthritis: what's in a name? Joint Bone Spine 2012;79:534-5.

4. Moll JM, Wright V. Psoriatic arthritis. Semin Arthritis Rheum 1973;3:55-78

5. Saraux A, Guillemin F, Guggenbuhl P, et al. Prevalence of spondyloarthropathies in France: 2001. Ann Rheum Dis 2005;64:1431-5.

6. Rouzaud M, Sevrain M, Villani AP, et al. Is there a psoriasis skin phenotype associated with psoriatic arthritis? Systematic literature review. J Eur Acad Dermatol Venereol 2014;28(Suppl 5):17-26.

7. Ash ZR, Tinazzi I, Gallego CC, et al. Psoriasis patients with nail disease have a greater magnitude of underlying systemic subclinical enthesopathy than those with normal nails. Ann Rheum Dis 2012;71:553-6.

8. Freeston JE, Coates LC, Helliwell PS, et al. Is there subclinical enthesitis in early psoriatic arthritis? A clinical comparison with power Doppler ultrasound. Arthritis Care Res (Hoboken) 2012;64:1617-21

9. Aydin SZ, Castillo-Gallego C, Ash ZR, et al. Ultrasonographic assessment of nail in psoriatic disease shows a link between onychopathy and distal interphalangeal joint extensor tendon enthesopathy. Dermatology 2012;225:231-5.

10. Tan AL, Tanner SF, Waller ML, et al. High-resolution [18F]fluoride positron emission tomography of the distal interphalangeal joint in psoriatic arthritis-a bone-enthesis-nail complex. Rheumatology (Oxford) 2013;52:898-904.

11. Horreau C, Pouplard C, Brenaut E, et al. Cardiovascular morbidity and mortality in psoriasis and psoriatic arthritis: a systematic literature review. J Eur Acad Dermatol Venereol 2013;27(Suppl 3):12-29.

12. Ogdie A, Haynes K, Troxel AB, et al. Risk of mortality in patients with psoriatic arthritis, rheumatoid arthritis and psoriasis: a longitudinal cohort study. Ann Rheum Dis 2014;73:149-53.

13. Love TJ, Zhu Y, Zhang Y, et al. Obesity and the risk of psoriatic arthritis: a population-based study. Ann Rheum Dis 2012;71:1273-7. 
14. Haroon M, Gallagher $\mathrm{P}$, Heffernan $\mathrm{E}$, et al. High prevalence of metabolic syndrome and of insulin resistance in psoriatic arthritis is associated with the severity of underlying disease. J Rheumatol 2014;41:1357-65.

15. Li W, Han J, Qureshi AA. Smoking and risk of incident psoriatic arthritis in US women. Ann Rheum Dis 2012;71:804-8.

16. Tillett $\mathrm{W}$, Jadon $\mathrm{D}$, Shaddick $\mathrm{G}$, et al. Smoking and delay to diagnosis are associated with poorer functional outcome in psoriatic arthritis. Ann Rheum Dis 2013;72:1358-61.

17. Bremander A, Jacobsson LT, Bergman S, et al. Smoking is associated with a worse self-reported health status in patients with psoriatic arthritis: data from a Swedish population-based cohort. Clin Rheumatol 2014. Published Online First: 15 Jul 2014

18. Højgaard P, Glintborg B, Hetland ML, et al. Association between tobacco smoking and response to tumour necrosis factor $\alpha$ inhibitor treatment in psoriatic arthritis: results from the DANBIO registry. Ann Rheum Dis 2014. Published Online First: 25 Jul 2014. doi:10.1136/ annrheumdis-2014-205389

19. Palominos PE, Gaujoux-Viala C, Fautrel B, et al. Clinical outcomes in psoriatic arthritis: a systematic literature review. Arthritis Care Res (Hoboken) 2012;64:397-406.

20. Gossec L, de Wit M, Kiltz U, et al. A patient-derived and patient-reported outcome measure for assessing psoriatic arthritis: elaboration and preliminary validation of the Psoriatic Arthritis Impact of Disease (PsAID) questionnaire, a 13-country EULAR initiative. Ann Rheum Dis 2014;73:1012-19.

21. Coates LC, Hodgson R, Conaghan PG, et al. MRI and ultrasonography for diagnosis and monitoring of psoriatic arthritis. Best Pract Res Clin Rheumatol 2012;26:805-22.

22. Gossec L, Smolen JS, Gaujoux-Viala C, et al. European League Against Rheumatism recommendations for the management of psoriatic arthritis with pharmacological therapies. Ann Rheum Dis 2012;71:4-12.

23. Smolen JS, Braun J, Dougados M, et al. Treating spondyloarthritis, including ankylosing spondylitis and psoriatic arthritis, to target recommendations of an international task force. Ann Rheum Dis 2014;73:6-16

24. Coates LC, Navarro-Coy N, Brown SR, et al. The TICOPA protocol (TIght COntrol of Psoriatic Arthritis): a randomised controlled trial to compare intensive management versus standard care in early psoriatic arthritis. BMC Musculoskelet Disord 2013;14:101.

25. Wendling D, Lukas C, Paccou J, et al. Recommendations of the French Society for Rheumatology (SFR) on the everyday management of patients with spondyloarthritis. Joint Bone Spine 2014;81:6-14.

26. Paccou J, Wendling D. Current treatment of psoriatic arthritis: update based on a systematic literature review to establish French Society for Rheumatology (SFR) recommendations for managing spondyloarthritis. Joint Bone Spine 2014. Published Online First: 2 Jul 2014. doi:10.1016/j.jbspin.2014.05.003

27. Claudepierre P. Spondyloarthritis: a window of opportunity? Joint Bone Spine 2014;81:197-9.

28. Pertuiset E. Methotrexate in psoriatic arthritis. Joint Bone Spine 2014;81:107-9.

29. Wendling D, Guillot X, Prati C. The IL-23/Th17 pathway in spondyloarthritis: the royal road? Joint Bone Spine 2014. Published Online First: 19 Sept 2014. doi:10.1016/j.jbspin.2014.08.003

30. Suzuki E, Mellins ED, Gershwin ME, et al. The IL-23/IL-17 axis in psoriatic arthritis. Autoimmun Rev 2014;13:496-502.

31. Varada S, Tintle SJ, Gottlieb AB. Apremilast for the treatment of psoriatic arthritis. Expert Rev Clin Pharmacol 2014;7:239-50. 